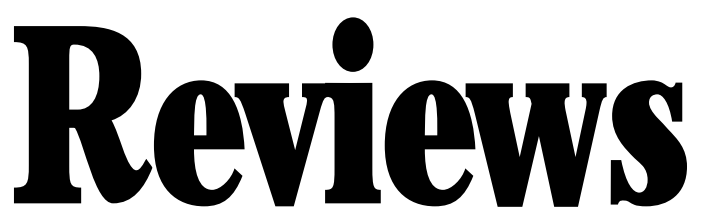

\section{Conservation Tillage for Vegetable Production}

\author{
G.D. H oyt' ${ }^{1}$, D.W. M onks², and T.J. M onaco ${ }^{2}$
}

Additional index words, no-till, strip-till, minimum-till, cover crops, weed control

\begin{abstract}
Summary. Conservation tillage is an effective sustainable production system for vegetables. N o-till planters and transplanters and strip-till cultivation equipment are presently available for most vegetables. Lack of weed management tools (herbicides, cultivators, etc.) continues to be the cultural practice that limits adaptability of some vegetables to conservation tillage systems. N itrogen management can be critical when grass winter cover crops are used as a surface residue. Advantages of using conservation tillage include soil and water conservation, improved soil chemical properties, reduction in irrigation requirements, reduced labor requirements, and greater nutrient recycling. H owever, disadvantages may include lower soil temperatures, which can affect maturity date; higher chemical input (desiccants and postemergence herbicides); potential pest carryover in residues; and enhancement of some diseases.
\end{abstract}

${ }^{1} \mathrm{D}$ epartment of Soil Science, $\mathrm{N}$ orth C arolina StateU niversity, M ountain $\mathrm{H}$ orticultural C ropsR esearch \& Extension Center, Fletcher, N C 28732-9628.

${ }^{2} \mathrm{D}$ epartment of $\mathrm{H}$ orticultural Science, $\mathrm{N}$ orth $\mathrm{C}$ arolina State U niversity, R aleigh, N C 27695-7609.

Theuse of tradenamesin thispublication doesnot imply endorsement by the $\mathrm{N}$ orth Carolina A gricultural $\mathrm{Re}$ search Service or Cooperative Extension Service, nor criticism of similar ones not mentioned. The cost of publi shing thispaper wasdefrayed in part bythepayment of page charges Under postal regulations, this paper ther efore must be her eby marked advertisement solely to indicate thisfact.
V egetable acreage in the $U$ nited States constitutes a relatively small percentage of farmland compared with agronomic crops such as corn, soybeans, and small grains. Although acreage planted to vegetables is small, production is intensive, with most growers using conventional cultivation practices. Recent advances in farm equipment and herbicides have afforded producers of vegetables the opportunity to grow their cropsunder some form of conservation tillage (Coolman and H oyt, 1993). Conservation tillage technology developed for agronomic crops is usually not directly applicable to vegetable production and must be modified. Such modifications require a strong management commitment and current knowledge of pesticides.

Benefits of conservation tillage practices have been discussed in previous publications dealing with agronomic crops (Blevins et al., 1977; Doran, 1987; Gallaher and Ferrer, 1987). A few of these apply to intensive culture of vegetable crops, including a decrease in time required to prepare fields for planting, a reduction in irrigation water required due to increased infiltration of rain and irrigation (M orse and Tessore, 1984), and an increase in organic residues from cover crops grown for soil improvement (H oyt, 1992).

U ndesirableconsequences of conservation tillage for vegetables include lower soil temperatures in spring resulting from mulching and shading effects of cover crop residues ( $\mathrm{H}$ oyt and Konsler, 1988) and potential overwintering of pests in surface residues from previouscrops. Reduced soil temperaturesmayslow thegrowth of some vegetable crops, possibly resulting in delayed maturity, thereby missing potentially lucrative early market prices. Reduced soil temperatures may not affect adversely cool-season vegetables such as cole crops, potatoes, and leafy greens, but may reduce early growth of warm-season crops such as tomatoes, sweet corn, snap beans, and squash planted in early spring (Bellinder et al., 1987; M cK eown et al., 1988; Petersen et al., 1986). G rowth of to matoes and other vegetables during the late spring and summer have not been affected by the changes in soil temperatures produced by residues in conservation tillage systems (D rost and Price, 1991b; M orse and Seward, 1986; M orseet al., 1982; Shelby et al., 1988; Wilhoit et al., 1990).

Problems with pests can be minimized by fall tillage of crop debris and then seeding the field with a grass or legumecover crop (Phatak et al., 1991). This will reduce pest carryover and provide sufficient residue for soil erosion control.

\section{Equipment}

Vegetable production using conservation tillage techniques requires seeding and transplanting equipment appropriate for planting in an undisturbed cover crop (no-till) or in atilled strip in the cover crop (strip-tillage). $D$ ifferent soil preparation equipment is required for strip-tillagethan is used for conventional tillage.

L arge-seeded vegetablecropssuch as sweet corn, snap beans, and squash may be planted in the undisturbed cover crop using no-till field corn or soybean planters (K navel et al., 1985; M ascianica et al., 1986; M ullins et al., 1988). N o-till planters should be fitted with a coulter (to cut through residue) and double disk openers to ensure proper placement and coverage of seed. N o-till planterswith seed plates can be used for some vegetables by carefully matching plates to seed size. Plateless no-till planters can accommodate a wider range of vegetable crops. Conservation tillage plantersfor small-seeded vegetables such as cole crops, carrots, onions, or radishes are 


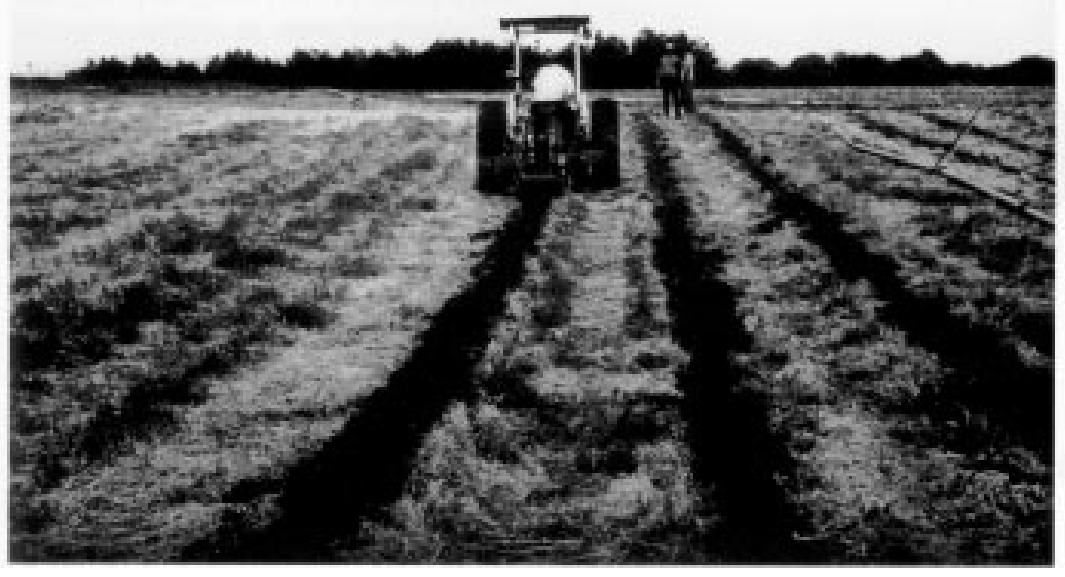

Strip-tillage equi pment cultivation a narrow band of soil in killed hai ry vetch res due before tomato transplanting.

being developed (M orse et al., 1987). $U$ se of gel seeding for better seed placement and improved emergence and survival has been investigated (D rost and Price, 1991a, Pill, 1991).

Seed bedsprepared through striptillage can be planted with equipment used with conventional tillage. Equipment used for transplanting to matoes, peppers, and cole crops by conventional methods are suitable for planting these same crops in strip-tillage culture. In addition, conventional transplanters have been modified to plant bare-root or containerized transplantsin undisturbed soil ( $M$ orrison et al., 1973a, 1973b; M orse and Seward, 1986; Wood and Worsham, 1986). A shank and a cutting coulter in front of the transplanter opens a slit in the soil for thetransplant. A heavier-than-normal pack wheel presses the soil around the roots.

Special equipment has been designed to prepare a seedbed for striptillageculture of direct-seeded or transplanted vegetables. A rotary powerdriven tiller, with all but thetwo middle tines removed, will produce a wellprepared seedbed 8 to 12 inches wide to the depth of the tines ( $L$ oy et al., 1987; M cKeown et al., 1988; Petersen et al., 1985). This technique is inefficient in that it has a high energy requirement and is relatively slow, making it impractical for commercial grow-

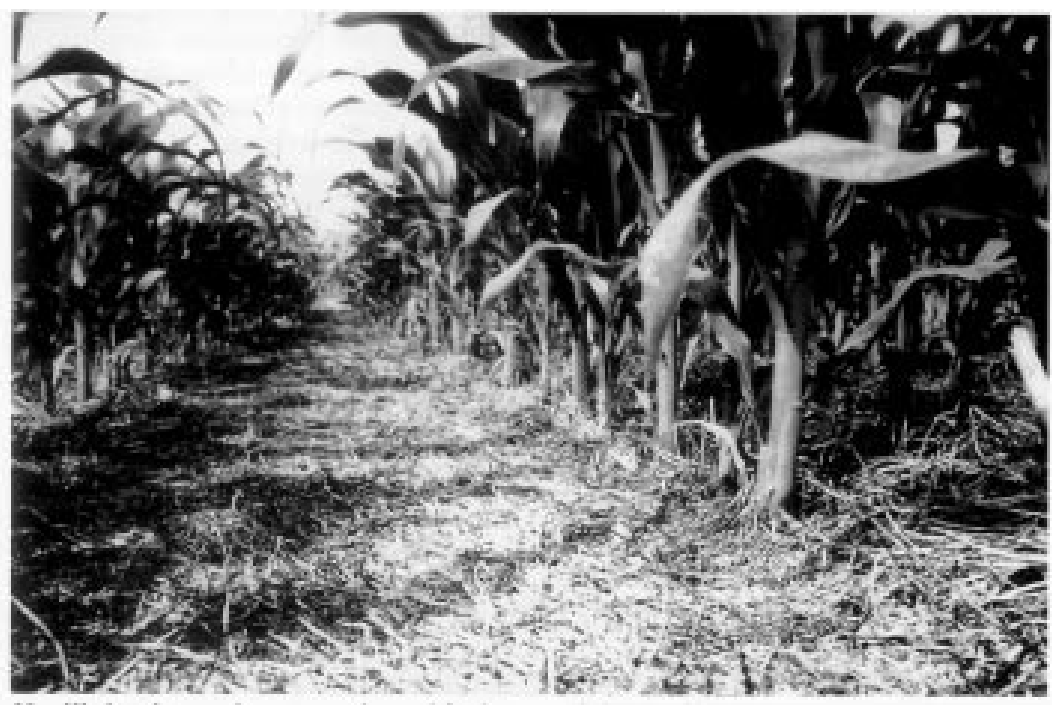

No-till planting equi pment can be used for large-seded vegetable crops.

ers. M ore-efficient implements are available that can prepare an 8- to 16inch-wide strip, subsoil, and travel at acceptable rates of speed ( $>1$ acre/ $h$ per row) (M ullins et al., 1988). These implementsuseafront-cutting coulter, a subsoiler, a set of two tilling coulters on each side of the subsoiler, and a rolling basket to break clods (H oyt, 1987; M orse et al., 1987). This equipment prepares the soil and can incorporate fertilizers as well as pesticides. Additionally, the equipment can be modified to fumigate the tilled strip prior to planting (Estes et al., 1985).

\section{$L$ and preparation and cover crop establishment}

Insect and disease buildup is associated with continuous annual cropping of the same or related crops and when crop residueisallowed to remain on the soil surface until the following growing season. As with conventional tillage, crop rotation and destruction of previous crop debris are very important in managing diseases and insects. Soil tillage associated with establishing fall cover crops will incorporate crop residues and provide an opportunity to add non-mobile fertilizer materials such as lime, phosphate, and possibly potash. Cover crops provide protection against water and wind erosion, and generate beneficial organic residue for the following year ( $\mathrm{H}$ oyt and $\mathrm{H}$ argrove, 1986). The choice of cover crops depends on the vegetable crop to be grown and the cropping season. Grass (small grains) cover crops offer good protection against soil erosion by water or wind and ample plant residue for early plantings of coolseason vegetables such as potatoes, cabbage, or broccoli ( $D$ itsch and Alley, 1991; H oyt, 1984). Grass cover crops can remove excess soil water in the spring, but may be detrimental if dry soil conditions exist. L egumes can develop abundant biomass and provide significant amounts of nitrogen (N) through symbiotic $\mathrm{N}$-fixation for warm-season vegetables such as tomatoes, sweet corn, snap beans, and squash (Hoyt, 1989; Knavel and Herron, 1986; Skarphol et al., 1987) and fallplanted colecrops (M orseand Seward, 1986).

No-till and strip-till implements can be used in grass or legume cover crops. With no-till, the vegetable crop can be planted at the time of cover crop desiccation, thus allowing for 


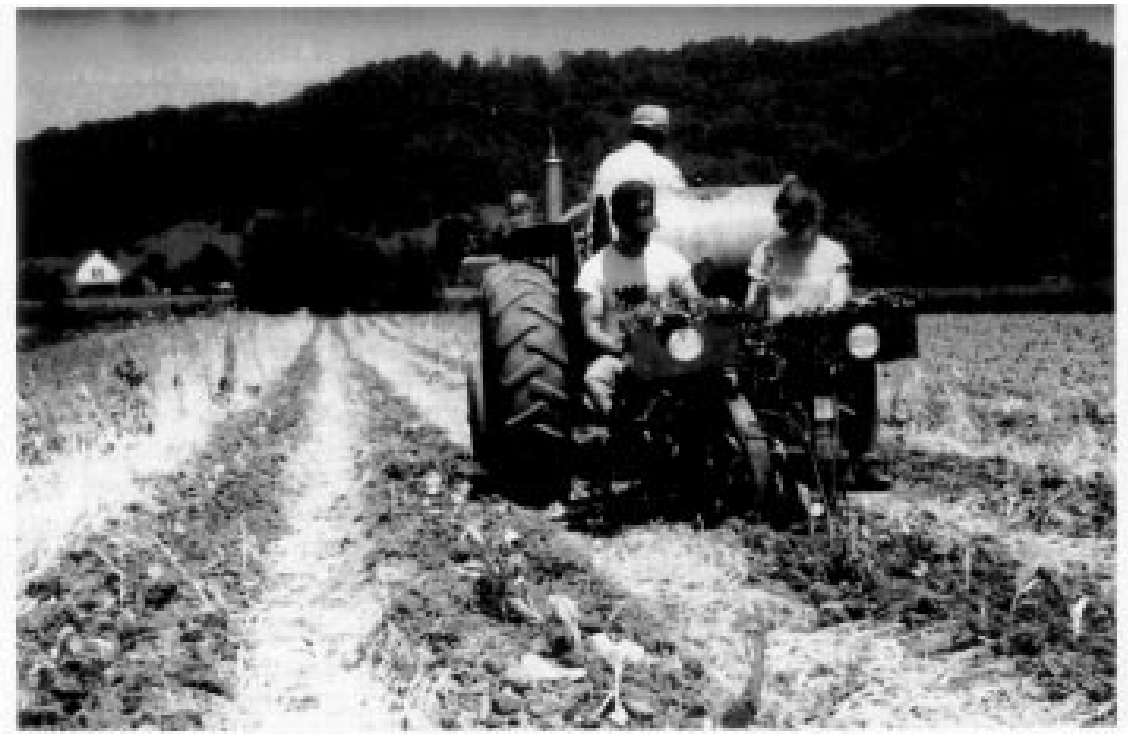

I Inicki, 1985), snap beans (Frank, 1990; N eary and M ajek, 1990; Vengris and Stacewicz-Sapuncakis, 1971; Williams et al., 1973), sweet corn (Williams et al., 1973), sweetpotato (Kasasian and Seeyave, 1969; L evett, 1992; T alatalaet al., 1977), and tomatoes(Friesen, 1978; G worgwor, 1990; Kasasian and Seeyave, 1969; M onaco et al., 1981; R ajagopal and Sankaran, 1980; Weaver, 1984; Weaver and T an, 1987) provides useful insights into when weed control or suppression is necessary to prevent yield and quality reductions from weeds.

Although management tools for insect and disease control are not affected greatly by production system (conservation or conventional tillage), management tools (cultivation, pre-

\section{Conventional transplanting equi pment can} be used in strip-tillage.

maximum cover crop development (and $\mathrm{N}$ accruement with legumes) and germination of weed seeds before application of the herbicide. With striptillage, the cover crop should be killed at least 1 to 2 weeks prior to soil preparation. This interval will allow initiation of the breakdown of cover crop rootsand reduce thetendency for clod formation.

\section{W eed management}

Weed interference (competition) studies have not been conducted with vegetable crops in conservation tillage systems. H owever, several studies have determined the critical weed-free period for specific weeds in vegetable crops in conventional systems. Information generated from weed interference studies in beets (H ewson and Roberts, 1973; Vengrisand StacewiczSapuncakis, 1971), broccoli (Bitterlich and U padhyaya,1990), cabbage (Bellinder et al., 1989; Lawson, 1972; Roberts et al., 1976; Weaver, 1984), carrots (Fiveland, 1974), cucumber (Friesen, 1978; Labrada et al., 1983; Lanini and Strange, 1991; Weaver, 1984), field beans (Dawson, 1964; Glasgow et al., 1976), lettuce ( $L$ anini and Strange, 1991; Roberts et al., 1977), limabeans (Glazeand M ullinix, 1984), muskmelon (N erson, 1989), onions (Williams et al., 1973), pepper (L anini and Strange, 1991; M eadt and M onaco, 1979), potato (I vany, 1986; Rioux et al., 1979; Saghir and M arkoullis, 1974; Sonmez and Karaca, 1975; Thakral et al., 1989; Vitolo and
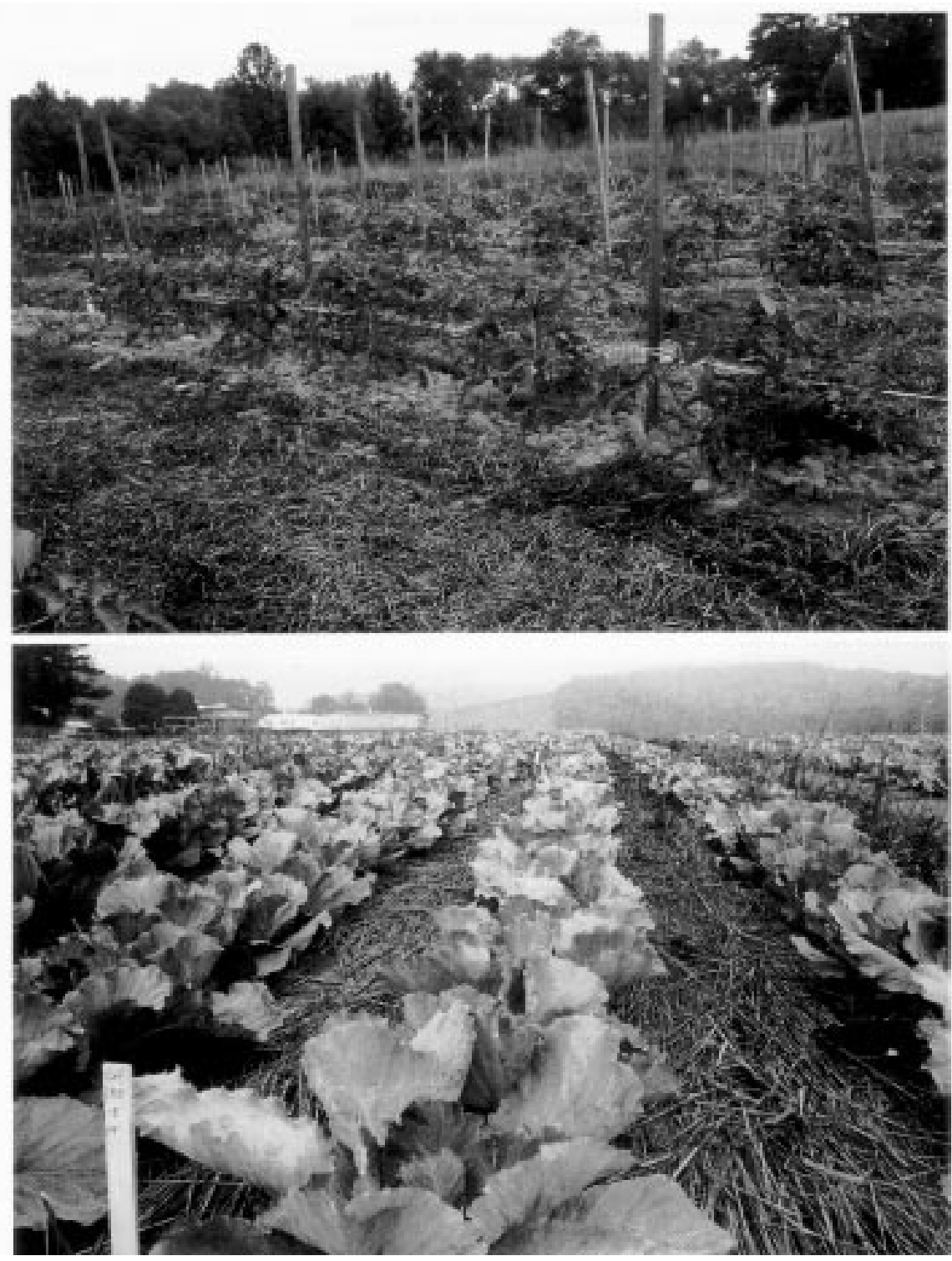

Strip-till fresh-market tomato production using hairy vetch (top) and cabbage using wheat residue (bottom). 


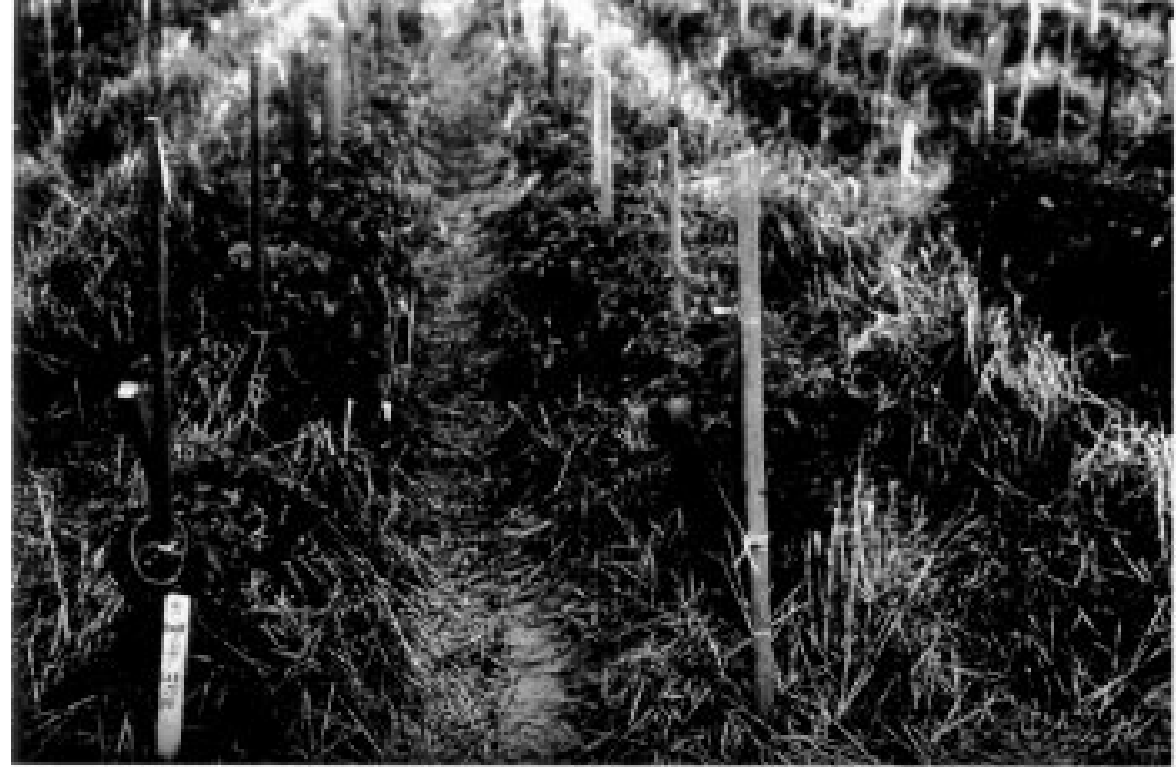

Tomato production using a no-till transplanter in rye residue.

plant herbicide application, etc.) for weed control are limited in a conservation tillage system. H owever, an effective weed management program is essential in the development of conservation tillage systems for vegetable crops. Several requirements must be met to achieve an effective weed management program in conservation tillage systems.

An effectiveherbicide for desiccation of live vegetation (cover crop, previouscrop, or weeds) prior to planting is necessary to establish a growth advantage of the crop over weeds. The herbicidemust providecompleteshoot kill and prevent regrowth of the previous crop or weeds. It should be capable of controlling all emerged plant

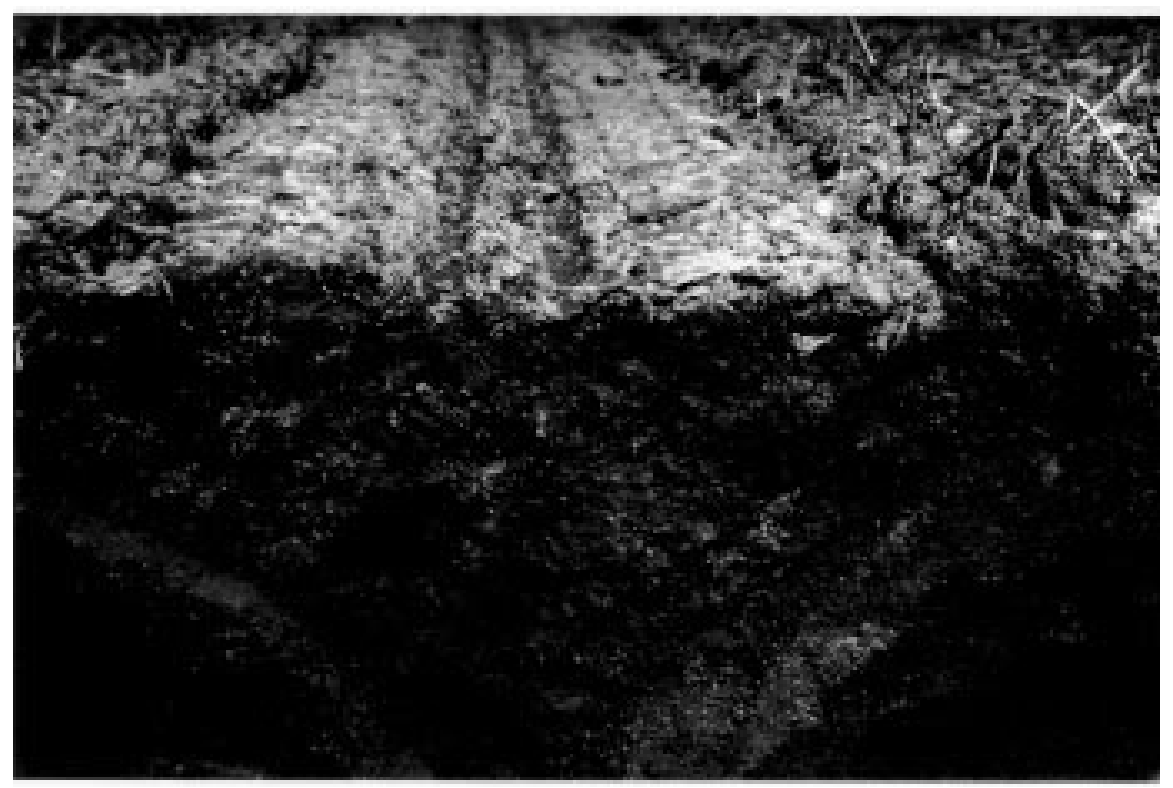

Strip-tillage produces loose cultivated soi I in the row area.
An effective preemergence herbicide program is required to control weeds that germinate after crop planting. The preemergence herbicide(s) should provide selective control and must be registered for the crop to be grown. Preplant soil-incorporated herbicides cannot be used in strictly notill systems, but can be used in the tilled strip in a strip-tillage system (Wilcut et al., 1990). More rainfall generallyisneeded to activatepreemergence herbicides in conservation tillage plantings. Because some of the herbicide is intercepted by the cover crop mulch, more rainfall or overhead irrigation is needed to movethe herbicide into the soil in comparison with herbicides applied in conventional tillage systems. Although not as many herbicides are registered for preemergence weed control in vegetable crops as in field crops, effective choices are available for crops such as beans, cabbage, potatoes, sweet corn, and tomatoes.

In conservation tillage systems, effective weed control after crop emergencealmost alwaysisrequired in early season to prevent the negative effects of weeds on yield and quality of vegetablecrops. Preemergenceherbicides do not provide complete control of every weed species present throughout the growing season in either conventional and conservation tillage systems. Therefore, cultivation and/ or use of a postemergence herbicide are required. Cultivation is impossible in most conservation tillage systems. $\mathrm{H}$ owever, early cultivation of the tilled strip in a strip-tillage system is possible during the first 2 to 3 weeks following crop emergence or transplanting.

Lack of effective postemergence herbicides can be a limiting factor in conservation tillage systems. Effective postemergence herbicides for control of annual grasses and broadleaf weeds are essential for a successful conservation tillage system. Vegetable crops that have postemergence herbicides registered and/ or have been successfully produced in a conservation tillage system areasparagus, beans, beets, cabbage, carrots, onions (dry bulb), peas, I rish potatoes, spinach, popcorn, sweet corn, and tomatoes. $M$ ajor vegetable crops that lack postemergence herbicides for control of broadleaf weeds include broccoli, cauliflower, cucurbits (cucumber, watermelon, muskmelon, squash, and pumpkin), pep- 
per, greens, okra, and sweetpotato. Production of these vegetable crops using conservation tillage will not be successful unlesshand-weeding ispracticed throughout the growing season or until effective postemergence herbicides are developed for these crops.

\section{Fertilizer recommendations}

Fertilizer rates and application methods must be adjusted when conservation tillage is used. A proper soil fertility program should be started in the fall when a grass or legume cover crop is being established. Soil should betested for each field or each soil type within the field to determine the correct amount and type of fertilizer for the following spring or summer vegetable crop. Prior to seeding the cover crop, the recommended lime, phosphorus, and potassium materials are applied (if fall leaching is not a problem), and the field tilled (if tillage is required) to incorporate the fertilizer materials and any crop and/ or weed residue. $\mathrm{N}$ itrogen and any other fertilizer materials that were not applied in the fall should be applied at vegetable planting the next year. Fertilizer is applied most effectively in a band to the side and slightly below the seed or transplant. Fluted coultersare required to cut through the residue and open a furrow for the fertilizer.

M ost fertility changes recommended for no-till agronomic crops also are applicable to conservationtilled vegetables. Specific adjustments include the following:

1) N itrogen application rateshould be increased based on density and type of cover crop and soil type used and for the inefficiency of placing fertilizer $\mathrm{N}$ on the surface. G rass cover crops tie up soil $\mathrm{N}$ in the spring, and grass residues have a slow rate of decomposition during the summer (Doss et al., 1981; H oyt, 1993; K navel and $H$ erron, 1981; Knavel and $\mathrm{H}$ erron, 1985; Knavel et al., 1977). Fertilizer $\mathrm{N}$ can be reduced if a legume cover crop is used (H oyt, 1991; Knavel, 1986; M orseand Seward, 1986; Skarphol et al., 1987);

2) Nitrogen, phosphorus, and potassium fertilizer materials should be band-applied rather than broadcast whenever possible to achieve greater efficiency (Robbins and Voss, 1991);

3) Starter fertilizer can be placed in transplant water to enhance initial root growth of the transplants; in seeded crops, starter material can be placed beside and below the seed;

4) U rea fertilizer materials should beincorporated or at least side-banded to reduce $\mathrm{N}$ loss.

\section{Vegetable crops for conservation tillage}

Vegetable crops easily adapted to a conservation tillage system are those that can be produced with planting equipment and pesticides similar to thoseused in producing conservationtilled agronomic crops. Large-seeded or transplanted vegetable crops perform successfully with conservation tillage. Small-seeded crops, such as lettuce, usually haveaslow earlygrowth rate, causing them to be extremely susceptible to competition by faster growing weeds. Germination of smallseeded crops often is inhibited by allelopathic chemicals produced by decaying cover crops. Popcorn (Knavel et al., 1985), sweet corn (Beste, 1973; Beste, 1974), snap beans (Bellinder et al., 1987; T ompkins et al, 1976), lima beans, and peas have been produced successfully in a conservation tillage system. Transplanted crops such as tomato (Beste, 1973; M onaco et al., 1986; Shelby et al., 1988), cabbage, and sweetpotato can be planted with modified no-till equipment or by planting with conventional equipment into a field that has been strip-tilled. Effective preemergence and postemergence herbicidesare registered for thesecrops, and yields have been excellent under these conservation tillage systems.

\section{L iterature C ited}

Bellinder, R.R., H.P. Wilson, and T.E. $H$ ines 1987. Comparative studies of conventional and no-tillage systems for snap bean production. H ortScience 22(1):159.

Bellinder, R .R ., D. Wilcox-Lee, A. Senesac, and D.T.Warholic. 1989. Response of earlymaturing cabbage (Brassica oleracea var. capitata) to metolachlor. Weed Technol. 3:463-466.

Bete, C.E. 1973. Evaluation of herbicides in no-till planted cucumbers, tomatoes, and lima beans. Proc. N ortheast Weed Sci. Soc. 27:231-239.

Beste, C.E. 1974. Evaluation of no-tillage vegetables in aryecover-crop mulch. Weed Sci. Soc. Amer. Abstr. 14:250.

Bitterlich, I. and M.K. U padhyaya. 1990. $\mathrm{L}$ ambsquarters interference with direct seeded broccoli. Can. J. Plant Sci. 70:12151221.
Blevins, R.L., G.W. Thomas, and P.L. Cornelius 1977. Influence of tillage and nitrogen fertilization on certain soil properties after 5 years of continuous corn. Agron. J. 69:383-386.

C oolman, R.M . and G.D. H oyt. 1993. The effects of reduced tillage on the soil environment. H ortT echnology3(2):143-145.

D awson, J.H . 1964. Competition between irrigated field beans and annual weeds. Weed Sci. 12:206-208.

Ditsch, D.C. and M.M. A lley. 1991. Nonleguminous cover crop management for residual $\mathrm{N}$ recovery and subsequent crop yields. J. Fert. I ssues 8(1):6-13.

D oran, J.W. 1987. M icrobial biomass and mineralizable nitrogen distributionsin notillage and plowed soils. Biol. Fert. Soils 5:68-75.

D oss, B.D., J.L. Turner, and C.E. Evans. 1981. Influence of tillage, nitrogen, and rye cover crop on growth and yield of tomatoes. J. Amer. Soc. H ort. Sci. 106(1): 95-97.

D rost, D.T. and H .C. Price. 1991a. Stand establishment of fluid-drilled tomato in rye and wheat tillage systems. H ortScience 26(12):1475-1478.

Drost, D.T. and H.C. Price 1991b. Effect of tillage system and planting date on the growth and yield of transplanted tomato. H ortScience 26(12):1478-1480.

Estes, E .A., W .A. Skroch, T.R . K onsler, P.B. Shoemaker, and K.A. Sorensen. 1985. N et economic values of eight soil management practices used in stake tomato production. J. Amer. Soc. H ort. Sci. 110 (6):812-816.

Fiveland, T.J. 1974. The competition between swedes or carrots and annual weeds. N orwegian Plant Protection Inst., D ept. of $\mathrm{H}$ erbology. Rpt. 114:2-15.

Frank, J.R . 1990. Influence of horsenettle (Solanum carolinese) on snapbean (Phaseolusvulgaris). Weed Sci. 38:220-223.

Friesen, C.H . 1978. Weed interference in pickling cucumbers (Cucumis sativus). Weed Sci. 26(6):626-628.

Gallaher, R.N . and M.B. Ferrer. 1987. Effect of no-tillagevs. conventional tillage on soil organic matter and nitrogen contents. Commun. Soil Sci. PlantAnal. 18(9):10611076.

Glasgow, J.L., J.W. Dicks, and D.R. H odgson. 1976. Competition by, and chemical control of, natural weed populations in spring-sown field beans (Vicia faba). Ann. Applied Biol. 84:259-269.

Glaze, N.C and B.G. Mullinix. 1984. Competitive effects of sicklepod on lima beans. Weed Sci. 32:1-3. 
Gworgwor, N .A. 1990. Growth and yield of irrigated tomato (Lycopersicon esculentum $M$ ill.) as affected by weed association. J. Agron. \& C rop Sci. 165:301-305.

H ewson, R .T. and H .A . R oberts. 1973. Effects of weed competition for different periods on the growth and yield of red beet. J. H ort. Sci. 48:281-292.

H oyt, G.D. 1984. The effect of cover crops on strip-till vegetableand tobacco production. Soil Sci. Soc. N orth Carolina Proc. 27:10-20.

H oyt, G.D. 1987. Conservation tillage for burley tobacco. 1987 Burley T obacco Information. N.C. Agr. Ext. Publ. AG 376. p. 22-24.

H oyt, G.D . 1989. Predicting nutrientsfrom winter cover cropsfor no-till management, p. 70-72. In: I.D. Teare (ed.). Proc. 1989 Southern C onservation Tillage C onf. Spec. Bul. 89-1. U niv. of Florida.

H oyt, G.D. 1991. Conservation tillage for burley tobacco: Selecting a surface residue. 1991 Burley Tobacco Information. N.C. Agr. Ext. Publ. AG 376. p. 31-34.

H oyt, G.D. 1992. Effect of cover crop and $\mathrm{N}$ rate on soil $\mathrm{N}$ and yield of no-till sweet corn and strip-till tomato. HortScience 27(6):663. (Abstr.)

H oyt, G.D. 1993. Conservation tillage for burley tobacco: $\mathrm{N}$ itrogen recommendations. 1993 Burley Tobacco I nformation. N.C. Coop. Ext. Publ. AG 376. p. 36-38.

H oyt, G.D. and W.L. H argrove 1986. Legume cover crops for improving crop and soil management in the southern U.S. H ortScience 21(3):397-402.

H oyt, G.D. and T.R. K onster. 1988. Soil water and temperature regimes under tillage and cover crop management for vegetable culture. Proc. 11th Intl. Conf., IST RO . Edinburgh, Scotland. p. 697-702.

I vany, J.A. 1986. Q uackgrass competition effect on potato yield. Can. J. Plant Sci. 66:185-187.

Kasasian, L. and J. Seeyave 1969. Critical periods for weed competition. PANS 15(2):208-212

K navel, D.E. 1986. E ffects of previous tillage system and nitrogen rates on yield and nitrogen concentration and recovery by turnip. H ortScience 21(6):1337-1338.

Knavel, D.E., J. Ellis, and J. Morrison. 1977. The effects of tillage systems on the performance and elemental absorption by selected vegetable crops. J. Amer. Soc. H ort. Sci. 102(3):323-327.

K navel, D.E. and J.W. H erron. 1981. Influence of tillage system, plant spacing, and nitrogen on head weight, yield, and nutrient concentration of spring cabbage. J.
Amer. Soc. H ort. Sci. 106(5):540-545.

Knavel, D.E. and J.W. H erron. 1985. Effect of sudan grass on yield and elemental content of cabbage. H ortScience. 20(4): 680-681.

K navel, D.E. and J.W. H erron. 1986. Response of vegetable crops to nitrogen rates in tillage systems with and without vetch and ryegrass. J. Amer. Soc. Hort. Sci. 111(4):502-507.

K navel, D.E., J.W.H erron, and G.M. White 1985. N o-till popcorn performs as well as conventionally grown popcorn. HortScience 20(1):136-137.

Labrada, R., E. Paredes, and R. Muniz. 1983. Weed competition in a cucumber crop. Trop. Pest M gmt. 29(1):52-55.

Lanini, W.T and M.L. Strange. 1991. L owinput management of weeds in vegetable fields. Calif. Agr. 45(1):11-13.

Lawson, H.M. 1972. Weed competition in transplanted spring cabbage. Weed Res. 12:254-267.

Levett, M .P. 1992. Effects of various handweeding programmeson yield and components of yield of sweet potato (I pomoea batatas) grown in the tropical lowlands of Papua, New Guinea. J. Agr. Sci. 118:6370.

Loy, S.J.W., L.C. Peirce, G.O. Estes, and O.S. Wells. 1987. Productivity in a strip tillage vegetable production system. $\mathrm{H}$ ortScience 22(3):415-417.

Mascianica, M.P., H.P. Wilson, R.F. Walden, T.E. H ines, and R.R. Bellinder. 1986. N o-tillage snap bean growth in wheat stubble of varied height. J. Amer. Soc. H ort. Sci. 111(6):853-857.

M cK eown, A.W .,R .F.C erkauskas, and J.W . Potter. 1988. Influence of strip tillage on yield, diseases, and nematodes of tomatoes. J. Amer. Soc. H ort. Sci. 113(3):328331.

M eadt, R.D . and T.J . M onaco. 1979. Prickly sida and cocklebur interference in transplanted peppers. Proc. South. Weed Sci. Soc. $32: 140$

M onaco, T.J ., A.S. Grayson, and D.C. Sanders. 1981. Influence of four common weed species on growth, yield, and quality of direct seeded tomatoes (Lycopersicon esculentum) Weed Sci. 29:394-397.

Monaco, T.J., G.D. Hoyt, and A.D. Worsham. 1986. Evaluation of no-tillage techniques for staked tomatoes. Proc. South. Weed Sci. Soc. 39:174.

M onks, D.W. and T.J. M onaco. 1993. 1993 Weed control recommendations in small fruits and vegetables. Dept. of $\mathrm{H}$ orticultural Science, N orth Carolina State U niv. p. 1-100.
Morrison, J.E., J r., D.C. M ilbocker, W.O. A tkinson, and J.H. Smiley. 1973a. Transplanter modification and survival of transplants under no-tillage conditions. $\mathrm{H}$ ortScience 8:483-485.

Morrison, J.E., J r., J.H .Smiley, W.O. A tkinson, and D.C. Milbocker. 1973b. A no-tillage transplanter. T obacco Sci. 17:44-46.

Morse, R.D. and D.L. Seward. 1986. N otillage production of broccoli and cabbage. Appl. Agr. Res. 1 (2): 96-99.

Morse, R.D. and C.M. Tessore. 1984. Efficient water use: conservation of soil moisture with no-tillage. T he V egetable G rowers N ews. 39(1):2, 4.

M orse, R.D., C.M. Tessore, W.E. C happell, and C.R. O'D ell. 1982. U se of no-tillage for summer vegetable production. The Vegetable Growers N ews. 37(1):1.

M orse, R.D ., D. Vaughan, L. Schertz, and A . Borowski. 1987. Strip tillage for production of direct-seeded broccoli. The Vegetable Growers N ews. 41(4):3-4.

Mullins, C .A ., R .A.Straw, and D .L. C offey. 1988. Production of snap beans as affected by soil tillage method and row spacing. J. Amer. Soc. H ort. Sci. 113(5):667-669.

N eary, P.E. and B.A. Majek. 1990. Common cocklebur (Xanthium strumarium) interference in snap beans (Phaseolus vulgaris). Weed Technol. 4:743-748.

N erson, H. 1989. Weed competition in muskmelon and its effects on yield and quality. Crop Protect. 8:439-443.

Petersen, K .L., H .J . M ack, and D .E. Booster. 1986. E ffect of tillage on sweet corn development and yield. J. Amer. Soc. H ort. Sci. 111(1):39-42.

Petersen, K.L., H.J. M ack, and R.H. Cuenca. 1985. Effect of tillage on the cropwater production function of sweet corn in western O regon. H ortScience 20(5):901903.

Phatak, S.C., R.L. Bugg, D.R. Sumner, J.D.Gay, K.E. Brunson, and R.B. Chalfant. 1991. Cover crop effects on weeds, diseases, and insects of vegetables, p. 153154. In: W.L. H argrove(ed.). Cover crops for clean water. Soil and Water Cons. Soc., Ankeny, I owa.

Pill, W.G. 1991. Advancesin fluid drilling. H ortT echnology 1(1): 59-65.

R ajagopal, A. and S. Sankaran. 1980. Crop-weed competition in tomato. $\mathrm{Ma}$ drasagric. J. 67(1):1-8.

R ioux, R ., J.E. Comeau, and H. Genereux. 1979. E ffect of cultural practicesand herbicideson weed population and competition in potatoes. Can. J. Plant Sci. 59:367-374.

R obbins, G.R . and R .D. Voss. 1991. Phos- 
phorusand potassium stratification in conservation tillage systems. J. Soil \& Water Cons. 46:298-300.

R oberts, H.A., W. Bond, and R .T. H ewson. 1976. Weed competition in drilled summer cabbage. Ann. Applied Biol. 84:9195.

R oberts, H.A., R.T. H ewson, and M.E. R icketts. 1977. Weed competition in drilled summer lettuce. H ort. Res. 17:39-45.

Saghir, A.R. and G. Markoullis 1974. Effects of weed competition and herbicides on yield and quality of potatoes. Proc. 12th British Weed Control Conf. 2:533-539.

Shel by, J r., P.P., D.L. C offey, G.N . R hodes, J r., and L.S. J effery. 1988. Tomato production and weed control in no-tillage versus conventional tillage. J. Amer. Soc. H ort. Sci. 113(5):675-678.

Skarphol, B.J., K.A. Corey, and J.J. $M$ eisinger. 1987. R esponse of snap beansto tillage and cover crop combinations. J. Amer. Soc. H ort. Sci. 112(6): 936-941.

Sonmerz, S. and I. K araca. 1975. Competition between annual weeds and potatoes and weed control. Turkish Phytopathol. $4(1): 35-43$.
Standifer, L.C. and C.E. Beste. 1985. Weed control methods for vegetable production with limited-tillage. p. 93-100. In: A.F. Wiese (ed.). Weed control in limited-tillage systems. Weed Sci. Soc. Amer. M onogr. 2.

Talatala, R., A.M. Mariscal, and A.C. Secreto. 1977. Critical periods for weed control in sweet potatoes. Philipp. J. Weed Sci. 5:1-6.

Thakral, K.K., M.L. Pandita, S.C. K hurana, and G. Kalloo. 1989. Effect of weed removal on growth and yield of potato. Weed Res. 29:33-38.

Tompkins, F.D., B.L. Bledsoe, and C.A. M ullins 1976. M inimum tillagesnap beans. Tenn. Farm and $\mathrm{H}$ omeSci. Prog. R pt. 98: 18-20.

Vengris, J. and M. Stacewiz-Sapuncakis 1971. Common puslanecompetition in table beets and snapbean. Weed Sci. 19(1):4-6.

Vitolo, D.B and R .D. I Ilnicki. 1985. G rass competition in white potatoes. Weed Sci. Soc. Amer. Abstr. 25:78.

Weaver, S.E. 1984. C ritical period of weed competition in three vegetable crops in relation to management practices. Weed Res. 24:317-325.

Weaver, S.E. and C.S. Tan. 1987. Critical period of weed interference in field-seeded tomatoesand itsrelation to water stressand shading. Can. J. Plant Sci. 67:575-583.

Wilcut, J.W., G.R. Wehtje, and T.V.H icks. 1990. Evaluation of herbicide systems in minimum- and conventional-tillage peanuts(A rachi shypogaea). Weed Sci. 38:243248.

Wilhoit, J.H., R.D. Morse, and D.H. Vaughan. 1990. Strip-tillage production of summer cabbage using high residue levels. Appl. Agr. Res. 5 (4): 338-342.

Williams, C.F., G. Crabtree, H.J. Mack, and W.D. Laws. 1973. E ffect of spacing on weed competition in sweet corn, snap beans and onions. J. Amer. Soc. H ort. Sci. 98(6):526-529.

Wood, S.D. and A.D. Worsham. 1986. Reducing soil erosion in tobacco fields with no-tillage transplanting. J. Soil and Water Cons. 41:193-196. 